\title{
ISLAMIC EDUCATION STUDENTS' PERSPECTIVE ABOUT ENGLISH SUBJECT
}

\author{
SULAIMAN \\ IAIN Pontianak, Indonesia \\ sulaimaniainptk@gmail.com
}

\begin{abstract}
This research aims to know the perspective of Islamic students about English subject. It reveals the questions such as: 1) what is the perspective of Islamic studies students towards English Subject in State Islamic Institute Pontianak?, 2) how does English learning process help Islamic studies students in State Islamic Institute Pontianak enrich their field study knowledge?. The research used mixed method. To answers the first research question, survey was used as research method, and questioner was used as instrument. Meanwhile, to answer the second research question, qualitative approach was chosen as method to gain answer. Interview was used as data collecting technique. The finding found that Islamic education students had positive perception dealing with the importance of learning English. The result also showed that English learning process on most of students' perspective had not been effective and it did not give much contribution in increasing students' English ability which deals with their disciplines. In conclusion, positive perception of students about the importance of learning English was not facilitated enough by learning process.
\end{abstract}

Keywords: Students' Perspective, Islamic Education Students, English Subject.

\begin{abstract}
Abstrak: Penelitian ini bertujuan untuk mendapatkan gambaran mengenai perspektif mahasiswa Pendidikan Agama Islam (PAI) terhadap Mata Kuliah Bahasa Inggris. Penelitian ini juga menjawab pertanyaan yang dikemukakan, yakni: 1) Apa perspektif mahasiswa PAI di IAIN Pontianak mengenai mata kuliah Bahasa Inggris?, 2) Apakah pembelajaran Bahasa Inggris yang dilakukan di IAIN Pontianak dapat membantu mahasiswa PAI untuk memahami disiplin keilmuan terkait? Mixed method dipilih sebagai metode untuk melakukan pengumpulan dan analisis data. Dalam pertanyaan pertama, bentuk survey dipilih sebagai metode penelitian, dengan instrumen berupa angket. Untuk pertanyaan kedua, pendekatan kualitatif dirasa cocok dan dipilih sebagai metode untuk memperoleh jawaban. Wawancara digunakan sebagai tehnik pengumpulan data. Pada akhirnya, ditemukan bahwa mahasiswa PAI memiliki persepsi positif terkait dengan pentingnya mempelajari Bahasa Inggris. Selain itu, hasil penelitian juga menunjukkan bahwasannya proses pembelajaran Bahasa Inggris di IAIN Pontianak oleh sebagian besar informan dianggap belum berjalan efektif dan tidak memberikan banyak kontribusi dalam upaya meningkatkan kemampuan Bahasa Inggris dan menghubungkannya dengan disiplin keilmuan terkait. Dengan demikian, persepsi positif mahasiswa tentang pentingnya mempelajari Bahasa Inggris belum difasilitasi dengan cukup baik oleh pembelajaran yang berlangsung.
\end{abstract}

Kata Kunci: Perspektif Mahasiswa, Mahasiswa PAI, Mata Kuliah Bahasa Inggris

\section{A. INTRODUCTION}

English is the international and official language of the globalization era. This is because globalization makes the world more narrow ${ }^{1}$. The world community is able to transcend these limitations by mastering global languages as a communication

${ }^{1}$ Zuliati Rohmah, "English as A Global Language: Its Historical Past and Its Future". Indonesian Scientific Journal Database. 1(Vol. 33, 2005,) 106. 
tool. Therefore, the global language becomes very important because of its function as a unified of various tribes, nations, ethnic, and religions throughout the world. In addition, the global language also functions as a means of conveying information from one individual or group to other individuals or groups throughout the world. Today, the global language that many people in the world uses is English.

This is in accordance with the perception and thought that language is a communication tool among members of the community in the form of sound symbols produced by human speech tools and is the most important thing in someone's life, because language is a human need in dealing with others. So the higher the level of mastery of one's language, the better the use of language in communication. As a communication tool, language must be mastered well in order to communicate well with others. Good language mastery is something that is sought and learned, moreover the language learned is a foreign language. The goals to be achieved by someone who is learning a foreign language, the ultimate goal is so that he can use the language both oral and written properly, fluently, and free to communicate with people who use the language

English becomes the main global connection (connecting language) for two reasons, namely geographical-historical and socio-cultural. ${ }^{2}$ English, used in the global world through the migration of people who speak English, colonization by the British, the role and influence of America on a global scale, international communication, media, film, technology, and others. In addition, English is the main language in trade, diplomacy, and education in the world. In the latest times like today, many research and scientific resources are written and presented in English. So, mastering English can be one of the doors to master the latest knowledge

Since the 18th century, science and technology have been written in English. This affects users of resources in English such as academics and students. Sources of knowledge written in English can be in the form of books, articles, and journals. This requires them to be able to speak English both written and oral. An academic or student will be widely recognized if their work can create a breakthrough that is beneficial to the world that is usually written or presented to the world community

2 David Crystal, English as Global Language (New York: Cambridge University Press, 2003), 29. 
using a global language, namely English. English is used not limited to all sectors, this is because of English as a means of communication for all citizens of the world about various lines.

In the world of education, English is the language of instruction within the scope of multidisciplinary science. The use of English in the field of multidisciplinary science gave birth to English for Specific Purpose (ESP) which focuses on gaining integrated professional expertise with a variety of skills, disciplines, and practices ${ }^{3}$. For example, English in the world of Education, Health, Economy, Law, Religion, and others. ESP aims to facilitate communication between actors in a particular field. Thus, ESP learning in the academic world is highly recommended to be encouraged, considering that each field always experiences its own development.

Seeing this reality, the State Islamic Institute Pontianak as one of the Islamic institute in Kalimantan which has various scientific disciplines aims to become a world-class campus that upholds mastery of foreign languages, both Arabic and English. This is evidenced by the international Journal such as Al Albab Journal. Islamic education in Indonesia has been ongoing since the entry of Islam into Indonesia. The process of entering Islam is inseparable from the role of language as a means of human communication in everyday life. With language, a person can convey ideas, thoughts, or feelings information to others both orally and in writing.

Because the demand for foreign language skills is increasing, along with advances in science, technology, information, and other fields. Someone can more freely establish communication with other people from different nationalities if he has good foreign language skills. Under these conditions, then learning a foreign language is very useful in understanding between individuals, groups and nations. Formal education that provides foreign language teaching one of which is an Islamic tertiary institution. In Islamic tertiary institutions, a foreign language is one of the subjects that students must not take except for students with a background in Islamic Religious Education (PAI).

${ }^{3}$ Vijay Bhatia, et al, ESP in the 21th Century: ESP Theory and Application Today. Proceeding of JACET 50th Commerative International Convention, 9. 
In this century, Islamic studies are not only accessible through Arabic references, but also literature in English. If many Islamic students have an Islamic background, it is not difficult for them to access Arabic resources. However, if they are required to access learning resources in English, this then arises as a problem. From this background, the researchers tried to uncover the views of students with Islamic majoring backgrounds on learning English at IAIN Pontianak.

Based on the writer's observation since the author entered the Islamic tertiary institution until now, the perspective of students, especially PAI students in various generations, most of them understand that English is the No. 1 international language in the world, but some people think that mastering English is unnecessary for those who do not interested in going abroad or because some people assume that they will only teach religious subjects in Indonesia in the future so that English language skills are not needed without thinking that Islamic preaching is not only done in domestic but also abroad, without thinking that now is the era of globalization, etc. With the above reasons, it becomes very important for students to have a positive perspective on English learning at IAIN, especially for students majoring in Islamic backgrounds, for example, PAI. Thus, the teaching staff / lecturer must make perspective as one of the main considerations for achieving the desired learning objectives.

\section{B. ENGLISH SUBJECT VIEWED BY PRESPECTIVE OF ISLAMIC EDUCATION STUDENTS}

In this century, English has become the global language of the world. In any world where someone is, as long as using English the communication will be understood by the interlocutor. As an example in Lombok and Bali , all international visitors use English as the main language of communication with the local community. Likewise, when visiting another country, the language used to communicate is the global language. English is not only an international language that is only used when there is communication between two people from two or more countries. For example, Arabic, which is an international language, is used when people from different countries meet Arabs. Likewise, Japanese is used only when someone is in an environment where people, traditions or businesses are 
dominated by people who speak Japanese. This is different from English, whose use spreads throughout the world even though it has nothing to do with Englishspeaking countries. In other words, English is the world's lingua franca which is a communication tool between people from different countries. Based on this fact, English is then said to be a global language.

As a global language, of course, its use is not only as a medium of verbal communication but also in various aspects of life such as computer programming languages, product manuals, educational resources, economics, etc. ${ }^{4}$ In fact, in the education curriculum, English is not only taught in countries that speak English as the main language but in almost all countries throughout the world. ${ }^{5}$ With a very massive use in almost all aspects of life, learning English is a need that cannot be denied. With its status as a global language, English is used also in terms of publications ranging from books, journals, research, and scientific seminars. It aims to widen the reach of readers or participants from the books or seminars held. In other words, a researcher and scientist, if they want their work to have an influence and are known internationally, then they must publish it in English. ${ }^{6}$

Regarding the use of English, the data shows that about one billion websites use English from various fields of science which will make it easy for users to get information. Furthermore, it is known that the publication of research results which reaches $90 \%$ is written in English. ${ }^{7}$ Coupled with books of knowledge both written by English, American authors or the translation of other languages. From these sources, including sources of knowledge related to religion.

This is certainly very helpful for academics to broaden their knowledge, especially based on the latest sources. This is because the development of religious knowledge is always marked by the latest and ongoing research; terrorism, radicalism, ISIS aggression, etc. In addition, English is the main language in the source that discusses religions that emerged in European regions such as Christianity

\footnotetext{
${ }^{4}$ David Crystal, English as a global language (Cambridge: Cambridge University Press, 1997), 42.

${ }^{5}$ David Graddol, The Future Of English? (London: The British Council. 1997), 60.

6 The Atlantic. 2015. The Hidden Bias of Science's Universal Language. www.theatlantic.com. (Diakses pada 10 April 2015), 4.

7 Robert B Kaplan, Language in The Global Context: Implication for The Language Classrooms (Singapore: SEAMEO RECL, 2000), 22.
} 
and Catholicism. By enriching the sources of religious knowledge, this will also add to the scientific treasures in the field. For example, academics can have different perspectives, especially from different groups.

As academics, students are required to always be critical in responding to any national or international issue. To meet these challenges, a complete understanding is needed so those objective and comprehensive responses can be generated. For example, student comparative religion; when they discuss about history of other religion, the main reference used is books or journals published from European countries which of course use English. Thus, a good mastery of English can help students to enrich their insights related to the field of science occupied. ${ }^{8}$ Seeing the phenomenon that the discussion of religious issues at this time many use English, it has become a necessity that students with a religious education background need to master English as a tool to find out current religious issues and to publish the results of their thought and research.

In a learning process, the perspective of each individual plays an important role in the process of achieving the objectives of the learning undertaken. Perspective will affect the behavior, attitudes, responses and motivation possessed. ${ }^{9}$ In other words, a positive perspective on something will make a person have the motivation to realize that something. For example, when someone has a positive perspective on English, they will try to learn and master it by participating in learning activities in class properly or even going to look for additional classes or activities to improve their abilities. Vice versa, when someone is apathetic towards English, then laziness to participate in learning activities will arise. The impact that will arise then is that the student will not participate maximally in the classroom.

Related to this, expert by Dornyei suggested explaining the importance of the material taught to students at the beginning of each lesson. ${ }^{10}$ This is intended so that students know that the learning conducted will be able to help them to improve their

\footnotetext{
${ }^{8}$ Muhammad H. Al-Khairi, "English as A Foreign Language Learning Demotivational Factors As Perceived By Saudi Undergraduates", European Scientific Journal, (November, 2013), 9.

${ }^{9}$ Ismail sheikh Ahmad, et al., "Attitudes and Motivation toward Learning the English Language among Students from Islamic Education System Background: Exploring the Views of Teachers", Journal of Education and Learning. 3 (Vol.8, 2014), 195-208.
}

10 Zoltan Dornyei, Teaching and Researching motivation (Harlow: Longman, 2001), 39. 
competencies. According to Lightbown, even though there is no research that proves that perspective influences the achievement of learning goals, there is enough evidence from experience that a positive perspective is related to the willingness to keep learning. ${ }^{11}$ In other words, the student perspective is an inseparable part of the learning process.

With the above reasons, it becomes very important for students to have a positive perspective on English language learning at IAIN Pontianak, especially for students majoring in Islamic Education backgrounds. So, the teaching staff must make perspective as one of the main considerations in order to achieve the desired learning objectives.

\section{Method of Research}

This research used a mixed approach model or commonly known as mixedmethod to answer the question research. Creswell defines mixed methods as a series of procedures for data collection and analysis that optimize the use of both qualitative and quantitative. ${ }^{12}$ In this study, a quantitative approach is used to answer the first question, while the qualitative approach is used to answer the second question.

To answer the first question, the type of quantitative research used is a survey study. Described by Creswell, survey studies are a series of procedures in quantitative research, where questionnaires are usually used as data collection instruments, which want to describe the attitudes, opinions, behavior, or nature of a group of samples or population. Surveillance studies do not use manipulation in the research process. In another sense, what is done in the survey study is limited to a description of the situation that occurred, without any effort from the researcher to provide action. Next, the second question related to students' views on how connected English is with their scientific discipline, is answered with a qualitative approach. For this purpose, descriptive qualitative is used as a method of data collection and analysis. As a reason for the selection, this study only aims to describe how students perceive the process of learning English at IAIN Pontianak.

11 Patsy M. Lightbown and Nina Spada, How Languages are Learned (Oxford: Oxford University Press, 2008), 48.

${ }^{12}$ John W. Creswell, Educational Research (Lincoln: Pearson, 2012), 22. 


\section{Research Subject}

As mentioned above, there are two models of approaches used in this study, namely qualitative and quantitative. Subjects taken in the two studies are the same, but with different amounts. Students with Islamic education in Tarbiyah/ Teaching and Education Faculty at IAIN Pontianak were chosen as research subjects. To answer the first question, 100 students were taken as randomly selected samples. Whereas the second question, which used a qualitative design, only took 25 students as research informants.

\section{Research Instruments}

Questionnaires and interview guides are two instruments used by researchers to collect data. The Questionnaire, in this case, is used to answer the first question. In the questionnaire used, there were 10 questions in Indonesian that would help researchers find out what students' perspectives were about the importance of learning English. The questions in the questionnaire were written based on the adaptation results from various sources and observers of the researchers. Then, the interview guides were used with the aim of helping researchers to answer the second question related to students' views on the sustainability of the English learning process at IAIN Pontianak. In the interview guide, there are four main questions raised by the informant.

\section{Data Collection Techniques}

The first thing that was done by the researcher was distributing questionnaires to the participants. Then, after collecting data to find out the answer to the first question, the researcher called back as many as 25 participants to return to be the subject of the second study. The selected participants came from Islamic Education Study Program.

\section{Data Analysis Techniques}

In a study, data analysis techniques have a significant role on the grounds that the data analysis techniques will determine how researchers interpret the data obtained. ${ }^{13}$

${ }^{13}$ Nazir, Moh., Metode Penelitian (Jakarta: Ghalia Indonesia, 2013), 364. 


\section{a. Research Questions 1}

1) Data collected

2) The researcher groups the data into tabular form

3) The researcher determines the percentage range of each of the available options; Strongly agree, agree, less agree, disagree.

4) The researcher calculates the percentage of each statement using a Likert scale, then classified into the range of percentages that exist. For example, the percentage of student responses to the first statement (after calculated on a Likert scale) is $97 \%$, which means that it is strongly agreed. Then their perception is positive, in the sense that they agree that learning English is important.

5) After determining the percentage of each question, the researcher outlines the number of negative and positive percentages.

6) Researchers draw conclusions; if the number of statements with a positive percentage is more, then the student's response is positive, and vice versa.

b. Research Questions 2

1) Data collected from the results of the interview

2) Each answer to the interview question is categorized by using a pie chart

3) Researchers, through students answers try to find the causes or the reason for the answer and outline it (points of issue)

4) Conclusions are drawn based on available data.

\section{FINDING AND RESULT OF RESULT}

The perspective of Islamic Education student about the Importance of Learning English. In this study, to answer the first question about "What is the perspective of Islamic Education student at IAIN Pontianak about the importance of learning English?", There are ten statements related to the important role of learning English by Islamic Education student at IAIN Pontianak and it is intended to measure the perspective of students about the importance of learning English. As presented in the previous chapter, the research subjects to answer the first research question were 100 Islamic Education students who were randomly drawn from the first semester to the final semester in the undergraduate program. 
The first statement about "I study English because it is a global language" received a positive response with a percentage of $83.50 \%$ of the total students. In another sense, the first statement received a positive response from students who became research participants. Most of them agree that English is a global language, so students learn it. As for the second statement, the student's response is a negative statement. The statement "I am a student with Islamic studies, so I don't need English much" has a negative response with a score of $57.50 \%$. This indicates that more than half of the sample of students with a background in Islamic majors, although not from Islamic studies, still requires English in learning in their respective majors, it is because negative statements are responded negatively, resulting in positive meanings.

The third statement, namely "I study English to access learning resources in English" received a 75\% response rate from 100 participating students. This is an indication that the majority of the sample of students with Islamic backgrounds majoring in studying English is because the literature they use that is related to their majors uses English. Furthermore, the fourth statement which reads "I prefer to be comfortable learning in Indonesian, rather than learning in English" received a negative response with a percentage of $65.25 \%$. This proves that more than half of those involved as research participants, in addition to studying in Indonesian also did not close themselves to study in English.

The fifth statement that read "Learning English can help me get a lot of new information that I can link with my scientific discipline" received a positive response from participants or research respondents. This is evidenced by the large percentage obtained by this statement, which is $79.25 \%$. This means that students agree with the proposed dictum that one of the benefits gained by students from learning English is their ability to access new information related to their respective scientific disciplines. In other words, few students with Islamic majors who did not benefit from studying English at IAIN Pontianak. Furthermore, the sixth statement about "all interactions that I do with lecturers and classmates, do not use English. Thus, learning English will not be of much use to me "getting a negative response with a percentage of $53.50 \%$. This means that although English is not used as the main language of 
instruction, they do not choose to be apathetic about the importance of learning English.

The seventh statement stated, "It is important for me to study English to open and broaden my horizons" to get a percentage of $84.50 \%$ of the sample responses of students with an Islamic education background. This means that students responded positively to statement number seven, which means that most of the sample of students assumed that learning English could help them develop insights by studying Islamic literature in English. The next statement was "Learning English can broaden my perspective" received a response of $81.25 \%$. This indicates the assumption of most of the sample of students that by learning English, they can have a wider and more open perspective than before.

The next statement, namely the ninth statement "By learning English, I will be helped a lot to achieve higher academic achievement in my field of study" received a positive response from a sample of students with a background in Islamic major with a percentage of $77.50 \%$. This means that most students with a background in Islamic studies are helped to achieve a wider range of scholarship through learning English. Finally, the tenth statement "It is not too important for me to learn English, because it is the language of western people." Received an $83 \%$ response which means the response "disagree" from a sample of students with Islamic majors because most of them consider learning the language English is important for the reason that English is not just the language of western people.

In a learning process, the perspective of each individual plays an important role in the process of achieving the objectives of the learning undertaken. Perspective will affect the behavior, attitudes, responses and motivation possessed. In other words, a positive perspective on something will make someone have motivation to realize something. For example, when someone has a positive perspective on English, they will try to learn and master it by following learning activities in class well or even will look for additional classes or activities to improve their abilities. Vice versa, when someone is apathetic towards English, then a lazy attitude to follow learning activities will arise. The impact that will arise later is that the student will not participate maximally in the class. Related to this, Dornyei $(2001 ; 40)$ suggested 
explaining the importance of the material taught to students at the beginning of each lesson.

This is intended so that students know that the learning conducted will be able to help them to improve their competencies. According to Lightbown, though there is no research that proves that perspective influences the achievement of learning objectives, but there is ample evidence based on experience that a positive perspective is related to the willingness to keep learning. In other words, student perspective. From the data presented above, there are ten statements related to the important role of learning English towards students with Islamic Education environment and it is intended to measure students' perspectives on the importance of learning English. From the 10 statements, it was found that all statements, either with positive or negative editors, were responded positively by students who were respondents of the study. In another sense, all statements have a meaning that is responded positively by a sample of students, so it can be said that the perspective of students on the importance of learning English is positive.

\section{E. CONCLUSION}

Based on the results of data analysis conducted in the study, related to the first question, it can be seen that students who are involved as respondents give a positive response to the assumption that learning English is important. This indicates that Islamic Education students consider learning English as necessary. Related to the second question, namely students' perceptions about whether English learning conducted at IAIN Pontianak has been able to help them understand the discipline their respective scholarship, the results of the interviews showed that most of the students assumed that learning had not been able to contribute much to their efforts in integrating English language skills with the disciplines occupied. This is caused by the ineffectiveness of the learning process carried out so that students cannot do much with their English language skills. Aside from the two things above, another thing that can be concluded from this study is the discovery of the fact that Islamic Education students have assumed that learning English is a necessary thing, but it is not sufficiently facilitated properly by the learning process that has taken place. To overcome this, there are a number of inputs given by students, namely improving the 
quality of lecturers both in content and pedagogy, providing adequate communication space, and adjusting learning material to student scientific needs (ESP). Nowadays, many religions use English, it has become a necessity that students with a religious education background need to master English as a tool to find out current religious issues and to publish the results of their thought and research.

\section{REFERENCE}

Al-Khairi, Muhammad H., "English as A Foreign Language Learning Demotivational Factors As Perceived By Saudi Undergraduates", European Scientific Journal, 9 (November, 2013)

Bhatia, Vijay, et al, ESP in the 21th Century: ESP Theory and Application Today. Proceeding of JACET 50th Commerative International Convention.

Creswell, John W, Educational Research. Lincoln: Pearson. 2012.

Crystal, David, English as Global Language. New York: Cambridge University Press, 1997.

Crystal, David. English as Global Language. New York: Cambridge University Press, 2003.

Dornyei, Zoltan, Teaching and Researching Motivation. Harlow: Longman. 2001

Gardner, R. C. The Attitude Motivation Test Battery: Technical Report 1. University of Western Ontario: London. 1985.

Graddol, David, The Future Of English?. London: The British Council. 1997.

Kaplan, Robert B, Language in The Global Context: Implication for The Language Classrooms. Singapore: SEAMEO RECL. 2000.

Lightbown, Patsy M. and Nina Spada, How Languages are Learned. (Oxford: Oxford University press, 2008.

Nazir, Moh, Metode Penelitian. Jakarta: Ghalia Indonesia, 2012.

Rohmah, Zuliati. "English as A Global Language: Its Historical Past and Its Future". Indonesian Scientific Journal Database. Vol. 33, 2005.

Rohmah, Zuliati. "English as global Language", Journal Bahasa dan Seni, Universitas Negeri Malang. 2015. 
Sheikh, Ismail Ahmad, et al., "Attitudes and Motivation toward Learning the English Language among Students from Islamic Education System Background: Exploring The Views of Teachers", Journal of Education and Learning, Vol. 8, 2014.

The Atlantic. The hidden Bias of Science's Universal Language. 2015. 